\title{
GIVING EFFECT TO REFUGEE CHILDREN'S FUNDAMENTAL RIGHTS TO LIFE AND A BASIC EDUCATION
}

\author{
Erika Serfontein \\ BA (Law) B.IURUS LLB HOD FDE (LSEN) MEd \\ $P h D$ \\ Professor, North-West University \\ Research Unit: EduHRight
}

\section{SUMMARY}

A gap in research on the violation of the rights of refugee children to well-being and education - both prerequisites for living a good life - has been recognised internationally as well as nationally. This article endeavours to partially fill this gap by (a) presenting a background to the situation of refugees in South Africa in general and refugee children in particular, (b) delineating relevant concepts, (c) explaining the international and national legislative framework applicable to refugee children, (d) clarifying the role of education in the life of refugee children, (e) identifying the various challenges such children present for an inclusive education system, as well as (f) drawing conclusions and making recommendations on overcoming these challenges.

South Africa has experienced an overwhelming growth in refugees since its transition to democracy in 1994. In contrast to the 1951 Convention, which defines a refugee as someone who is incapable or reluctant to return to their country of origin owing to a justified fear of being oppressed on the grounds of race, religion, nationality, membership of a particular social group, or political opinion, studies found that refugees and their children from the rest of the African continent, as well as from as far afield as China, Bangladesh and Pakistan, mainly flee to this country to escape conditions of poverty, civil discord and even war in search of a better life. Instead of being welcomed, however, refugee children are often met with intimidation, hate, xenophobia, aggressive nationalism, exclusion and discrimination by South Africans on a daily basis.

By concentrating on refugee children and probing the results of significant studies indicating the persistent challenges facing the realisation of inclusive education in South Africa, the author advocates a humanitarian approach to refugee children in order to respect their dignity whilst recognising their rights to life and a basic education within the borders of South Africa.

The 1951 Convention Relating to the Status of Refugees: Article 1 UN Refugee Agency. http://www.unhcr.org/refworld/docid/3b00f1cc50.html (accessed 2018-09-14). 


\section{$1 \quad$ INTRODUCTION}

While ongoing research is being conducted into xenophobia and migration, enquiries into the violation of the education rights of refugee children have lagged behind. ${ }^{2}$ There is limited research output available on the well-being of refugee children as, for example, no specific universal determining factors regarding the expected well-being of this vulnerable group of people could be found. ${ }^{3}$ It is against this background that this article aims to identify the challenges pertaining to realising refugee children's right to a basic education while emphasising the benefit of education to enhance the overall well-being of humans.

The attainment of democracy in South Africa has not only led to the liberation of the country's previously oppressed society, but it has also turned it into a potentially safe destination for many expatriated people across the world seeking asylum. ${ }^{4}$ The Constitution of the Republic of South Africa Act, 1996, which endorses the belief that this country belongs to all who live in it, and also promises to improve the quality of life of all citizens and to free the potential of each person, brought new hope regarding the attainment of better life opportunities. ${ }^{5}$ Individual fundamental rights, including the rights to life ${ }^{6}$ and a basic education, ${ }^{7}$ are moreover guaranteed to everyone. This entails that, except for the right to vote, refugees are entitled to the same rights as South Africans. ${ }^{8}$

Notwithstanding this country's limited resources to meet the need for pertaining to housing, education, health care and employment, ${ }^{9}$ which, together with nutritional food, clean water and economic and physical security, are crucial basic human needs, ${ }^{10}$ refugees choose South Africa based on high expectations regarding the quantifiable benefits of a democracy.

The majority of refugees in South Africa come from the rest of the African continent (currently one of the least democratic continents in the world),

2 Meda "The Mist That They Declared to Be Over Is Still Around: Xenophobic Experiences of Refugee Children Living at a Community Centre in South Africa" 201415 Child Abuse Research 72 82; Foubister and Badroodien "African Migrant Youth, Schooling and Social Class in Cape Town" in Weis and Dolby (eds) Social Class and Education: Global Perspectives (2012) 127; Spreen and Vally "Monitoring the Right to Education for Refugees, Migrants and Asylum Seekers" 201218 Southern African Review of Education 71 72; Landau Exorcising the Demons Within: Xenophobia, Violence and Statecraft in Contemporary South Africa (2012) 113.

3 Greyling "The Expected Well-Being of Urban Refugees and Asylum-Seekers in Johannesburg" 201619 SAJEMS 232232.

4 Manicom and Mullagee "The Status of Asylum Seekers and Refugees in South Africa: An Independent Overview" 201039 Africa Insight 184184

Preamble.

Constitution s 11.

Constitution s 29.

Crush "Immigration, Xenophobia and Human Rights in South Africa" 20012 South Africa Migration Project.

9 Hook and Eagle Psychopathology and Social Prejudice (2002) 154.

10 Senkosi "Meanings and Understandings of Wellbeing: An Exploration of Somali Refugees' Conceptions of Human Wellbeing" 201545 Africanus 7279. 
especially from Zimbabwe and Mozambique. It is documented that Zimbabwean refugees ( 3 million by 2013) are mainly driven to flee their country of origin because of factors such as famine and poverty, as well as political and economic deterioration, leaving them particularly distressed. ${ }^{11}$ However, South Africa is also a popular destination for people fleeing from China, Bangladesh and Pakistan. ${ }^{2}$ In essence, refugees are seeking a better quality of life and economic opportunities for themselves and their children in South Africa. Fulfilling their hopes and giving effect to their rights, however, pose extreme challenges. ${ }^{13}$

As South Africa still struggles to realise the socio-economic needs of the majority of its own citizens 25 years into democracy, refugees are often not welcomed by South African citizens. Already having to compete for scarce resources such as job opportunities and basic service delivery normally associated with citizenship, citizens (especially those living in impoverished townships) are resentful at the idea of having to share resources with refugees. Such resentment has led citizens to xenophobic violent attacks ${ }^{14}$ and killings ${ }^{15}$ of refugees, especially since 2008.

Cassette, Erasmus, Welcome and Chemaly ${ }^{16}$ report on eight foreigners being killed, hundreds of Malawians being repatriated for fear of xenophobic attacks and 421 Zimbabweans being deported. This occurred after Goodwill Zwelithini, the reigning King of the Zulu nation, ostensibly insinuated in 2015, that refugees are a burden and do not belong in South Africa. The same authors criticise these insinuations by arguing that refugees are often used by state leaders as scapegoats in order to negate their responsibility for an increase of poverty, unemployment, crime, corruption and political disgruntlement in this country. The latter is underscored by Spreen and Vally ${ }^{17}$ who stress such statements assist in furthering hatred and intolerant attitudes among the general population.

On the other hand, Wasserman and Kabeya-Mwepu ${ }^{18}$ condemn the mainstream media for cultivating a feeling of distrust and promoting xenophobia by continuously reporting on negative issues pertaining to refugees, thus creating an atmosphere of prejudice and stereotyping. A study conducted by Landau and Jacobsen ${ }^{19}$ indicated that government, state

11 Pausigere "Education and Training Initiatives at the Central Methodist Church Refugee House in Johannesburg" 201331 Perspectives in Education 42 51; Rwandarugali Finding a Place in the City: A Case Study of Great Lakes Region Refugees in the Ethekwini Municipality (masters dissertation, University of KwaZulu-Natal) 2011133.

12 Mukonza "Immigration and Refugee Policies: Unpacking Policy Dilemmas in South Africa" 201146 Journal of Public Administration 13841385.

13 Pieterse Establishing a Framework for an Integrated, Holistic, Community Based Education Support Structure (doctoral thesis, Nelson Mandela University) 201072.

14 Spreen and Vally 2012 Southern African Review of Education 83.

15 Kemper "Xenophobia - Serious Prejudice against Foreigners ... with Violent Consequences" 2017 Servamus Community-Based Safety and Security Magazine 2828.

16 "Systematic Problems for Refugees" 2015 Without Prejudice 3435.

172012 Southern African Review of Education 72.

18 "Creating Connections: Exploring the Intermediary Use of ICTs By Congolese Refugees at Tertiary Educational Institutions in Cape Town" 20056 Southern African Journal of Information and Communication 9495.

19 "Refugees in the New Johannesburg" 200619 Forced Migration Review 4445. 
agencies, local communities and even police officers indirectly contribute to the problem by forcing refugees to return to their countries of origin, thus putting them in a dreary and defenceless position. As a result, refugees are not viewed as having the potential of benefitting the country; rather, they are stereotyped as threats to the economic and social interests of South Africans. ${ }^{20}$ Such stereotyping was recently exacerbated by proposed changes to the Refugees Act ${ }^{21}$ that would provide for refugees to be fostered in border camps, thus providing them with food and shelter to which many South Africans do not have access. ${ }^{22}$

Research conducted on refugee children reports on their also falling prey to hatred, discrimination and xenophobia, leading to troubling, fearful and prejudiced experiences that such children have to endure on a daily basis. ${ }^{23}$ This exacerbates their existing troubles as refugee children are already emotionally traumatised by the forced nature of leaving their homes. Their entire lives have been altered; their educational careers have been put on hold, their social lives disrupted while fearing the unknown and facing challenges adapting to a new life in a new cultural setting.

Such prejudiced human behaviour among South Africans towards refugees threatens not only the consolidation of peace and democracy ${ }^{24}$ but also systemically disrespects and violates the fundamental rights of refugees. ${ }^{25}$ The judiciary has condemned such conduct in the Institute for Human Rights and Development in Africa (on behalf of Esmaila Connateh and 13 others) vs Angola, ${ }^{26}$ as well as in Watchenuka $v$ Minister of Home Affairs. ${ }^{27}$ In the Angola case, the court expressed its indignation at African states that often resort to radical measures to protect their own citizens owing to the economic challenges faced by the continent. The Supreme Court of Appeal (SCA) in the Watchenuka case ${ }^{28}$ reminded all that human dignity has no nationality and is therefore inherent to all humans. The SCA, accordingly, cautioned that the dignity of everyone - citizen or refugee should be respected and protected at all times. In ruling that freedom to study is inherent to human dignity because of its potential for human fulfilment, the SCA emphasised the close link between the rights to education and life, an aspect that is discussed later. Although the SCA emphasised that the State is not obliged to allow all to enter the country, it must provide education to children who have lawfully entered the country.

20 Mukonza 2011 Journal of Public Administration 1387

33 of 2008.

22 Jordan "Why the Move of a Refugee Camp Will Fuel Xenophobia in South Africa?" (10 July 2017) https://www.businesslive.co.za/bd/national/2017-03-07-why-the-move-of-a-refugeecamp-will-fuel-xenophobia-in-sa (accessed 2018-10-14).

23 Meda 2014 Child Abuse Research 84.

24 Potgieter, Van der Walt and Wolhuter "Towards Understanding (Religious) (In)Tolerance in Education" 201470 HTS Theological Studies 14.

25 Steyn, Kotze and Taylor "Refugee Perceptions of the Port Elizabeth Refugee Reception Centre" 201141 Africa Insight 88103.

26 Case number 292/04, African Commission on Human and Peoples' Rights, May 2008, https://www.refworld.org/cases,ACHPR,51b6fd4e7.html (accessed 2019-08-02).

272004 (4) SA 326 (SCA).

28 Watchenuka $v$ Minister of Home Affairs supra par 25. 
Denying refugee children access to available education was accordingly found to be unlawful, as it infringes on their rights to human dignity and general well-being.

\section{CONCEPT CLARIFICATION}

Central concepts are now set out in order to ensure that they are understood within the relevant context of this article.

\section{Refugees}

A single international definition of the term "refugee" was accepted by the 1951 Convention Relating to the Status of Refugees; ${ }^{29}$ the definition places emphasis on people who cannot or are hesitant to return to their country of origin for fear of being unfairly discriminated against on the grounds of race, religion, nationality, membership of a particular social group, or political opinion. A definition more specifically applicable to the African continent was adopted in 1969 by the Organisation of African Unity. ${ }^{30}$ Refugees are defined to include all human beings who, because of external aggression, occupation, foreign dominance or events seriously disturbing public order in either part or the whole of their country of origin or nationality, are forced to leave their habitual residences in order to seek sanctuary outside their country of origin or nationality. Once such persons meet the criteria of a refugee and are admitted into asylum, they are entitled to be recognised before the law both as persons and specifically as refugees, and are thus entitled to the same rights and benefits as citizens. ${ }^{31}$

\section{The right to life}

"Life" is held as being God-given to all human beings and is thus not conferred to humans by the law. ${ }^{32}$ The right to life is a moral right independent of the law, since humans enjoy it simply by virtue of being human. ${ }^{33}$ The right to life is, nevertheless, guaranteed by the Constitution as a fundamental right belonging to everyone. Since the extent of this right is not legally defined, cognisance is taken of its various interpretations. Some authors $^{34}$ follow a narrow approach, restricting the right to life simply to the

29 The 1951 Convention Relating to the Status of Refugees: Article 1 UN Refugee Agency. http://www.unhcr.org/refworld/docid/3b00f1cc50.html.

30 The Organisation of African Unity Convention Governing the Specific Aspects of Refugee Problems in Africa, Article 1(2) adopted on 10 September 1969 by the Assembly of Heads of State and Government, CAB/LEG/24.3, entered into force on 20 June 1974.

31 Letsebe "Voyager or Victim? Refugees Are Not Holiday Travellers" 2014 July De Rebus 25 26.

32 Serfontein "The Nexus Between the Rights to Life and to a Basic Education in South Africa" 201518 PER 22652266.

33 Ajei "Human Rights in a Moderate Communitarian Political Framework" 201534 South African Journal of Philosophy 490491.

34 Currie and De Waal The Bill of Rights Handbook 6ed (2013) 267. 
right to breathe and to be physically alive. Others ${ }^{35}$ underscore a broader approach, propagating that the right to life includes, among others, the empowerment of everyone through all means to live full lives. Yet others are of the opinion that this right encompasses the right to live good lives, decent lives, ${ }^{36}$ an ethical quality of life, ${ }^{37}$ lives worth living ${ }^{38}$ or a meaningful existence for which peace ${ }^{39}$ and security, and access to the basic necessities of life, such as housing, education, employment and health care (socio-economic rights) as well as equality and full social and political participation, are prerequisites. ${ }^{40}$

Whichever approach is followed, it is evident that everyone's legally recognised right to life places both a negative and positive duty upon governments: a negative duty obliging governments to abstain from any action that may deliberately end a life; and a positive duty requiring governments to safeguard, preserve ${ }^{41}$ and enhance life ${ }^{42}$ by, inter alia, combatting diseases, rehabilitating health and providing adequate food and clean drinking water. ${ }^{43}$ Governments are, moreover, expected to create environments in which human dignity is respected so that, to the maximum extent of their available resources, they promote human survival and guarantee optimal development and well-being, which, in turn, require the holistic (physical, intellectual, emotional, spiritual, moral, psychological and social) well-being and development of every child. ${ }^{44}$

35 Boezaart "Wrongful Life - The Constitutional Court Paved the Way for Law Reform" 20152 Stellenbosch Law Review 399 420; Greyling "An Analysis of the Quality of Life of Migrants in Gauteng, A Province of South Africa" 20158 Journal of Economic and Financial Sciences 495 496; Watermeyer "Improving the Quality of Life Through Infrastructure: Civolution" 2013 13 Civil Engineering 56.

36 Refugees Amendment Act 33 of 2008.

37 Van Niekerk "The Need for Ethical Quality of Life Practices" 201455 Dutch Reformed Theological Journal 407408.

38 Serfontein "The Mammoth Task of Realising the Right to Life: A South African Perspective" in Boas (ed) Quality of Life and Quality of Work Life (2017) 168.

39 Ntlama "The Foundations of 'Peace' as a Value for the Promotion of Human Rights in Africa" 201717 African Human Rights Law Journal 5556.

40 Cassette et al 2015 Without Prejudice 35; Maguvhe "Inclusive Education: A Transformation and Human Rights Agenda Under Spotlight in South Africa" 20154 African Journal of Disability 14 ; Williams "Refugees and Social Theory: From the Politics of 'Bare Life' to Refugees as Political Subjects" 201446 Acta Academica 117119.

41 Sutherland "The Child's Right to Life, Survival and Development: Evolution and Progress" 20152 Stellenbosch Law Review 272282.

42 United Nations Convention on Human Rights "General Comment No. 6: Note by the Secretariat, Compilation of General Comments and Recommendations Adopted by Human Rights Treaty Bodies" (2008) UN Doc HRI/GEN/1/Rev.9.

43 OHCHR Manual on Human Rights Reporting Under Six Major International Human Rights Instruments (1997) reporting on article 6 of the United Nations Convention on the Rights of the Child. HR/PUB/91/1 (Rev.1), published by the Office of the High Commissioner for Human Rights.

44 Barnes "UNCRC's Performance of the Child as Developing" in Freeman (ed) Law Childhood Studies (2012) 425; United Nations Convention of the Rights of the Child "General Comment No. 14: The Right of the Child to Have His or Her Best Interests Taken as a Primary Consideration" (2013) UN Doc CRC/C/GC/14; Wicks "The Meaning of 'Life': Dignity and the Right to Life in International Human Rights Treaties" 201212 Human Rights Law Review 199201. 


\section{The right to a basic education in an inclusive education system}

The right to a basic education belongs to everyone regardless of colour, race, gender, class, religion, disability or culture. ${ }^{45}$ Since all the fundamental rights provided for in the Bill of Rights must be respected, protected, promoted and fulfilled by the State, ${ }^{46}$ public schools must equitably serve the educational needs of all children by guiding them to achieve a level of personal, academic, social, and occupational competence corresponding with their fullest potential. ${ }^{47}$ In order to achieve this, an inclusive education system was chosen for its potential to address the diverse needs of all learners equally in order to promote their optimal development, within one undivided education system.

When children are not educated in such a system, their rights to equality and a basic education are infringed upon. This was indeed the case in Western Cape Forum for Intellectual Disability $v$ Government of the Republic of South Africa. ${ }^{49}$ The High Court found that the right to a basic education is, for example, unjustly violated if children (in casu, severely impaired children) have to rely on non-government organisations, receiving less funding than public schools, for their education. It can be argued that the same applies to refugee children.

Inclusive education is defined as an educational system following a universal learning design to ensure the success of all, ${ }^{50}$ including learners who experience barriers to learning irrespective of their dissimilar personal or interpersonal needs as well as the circumstantial challenges they face. Barriers to learning embrace learning difficulties pertaining to reading, writing, mathematics, speech and language, as well as developmental delays and physical, neurological and sensory impairments. ${ }^{51}$ An inclusive education system aims at identifying and addressing all impediments to access, participation and belonging, thus achieving equity ${ }^{52}$ and equally empowering all learners with appropriate skills to discover the frontiers of knowledge ${ }^{53}$ and reach their full potential.

45 Churr "Realisation of a Child's Right to a Basic Education in the South African School System: Some Lessons from Germany" 201518 PER 2405 2409; Constitution, s 29 read together with $\mathrm{s} 9(3)$

46 Constitution, s 7(2).

47 Department of Education Education White Paper 6. Special Needs Education: Building an Inclusive Education and Training System (2001).

48 Ibid.

492011 (5) SA 87 (WCC), specifically par 4.

50 Kamga "Inclusion of Learners With Severe Intellectual Disabilities in Basic Education Under a Transformative Constitution: A Critical Analysis" 2016 49(1) Comparative and International Law Journal of Southern Africa 2430.

51 Hartgill "Identifying and Assessing the Child with Barriers to Learning" 2016 Jan/Feb Mental Health Matters 3133

52 Meltz, Herman and Pillay "Inclusive Education: A Case of Beliefs Competing for Implementation" 201434 South African Journal of Education 12.

53 Monyooe "Inclusive Education and Training Systems: Illusion or Reality? The Story of Nothemba" 200513 Education Policy Analysis Archives 113. 
Since barriers to learning and development are created $^{54}$ when an education system offers education inconsistent with the needs of learners, an inclusive education system needs to be fully operational within a nonthreatening, supportive learning environment establishing conducive learning circumstances. ${ }^{55}$ Although the inclusion of learners previously excluded from education in South Africa is generally envisaged, various authors ${ }^{56}$ urge that it must encompass a wider group of vulnerable and marginalised learners. Accordingly, there is a need for a reformed environment in which all learners feel welcome, thus including those who have experienced dangerous and risky life circumstances and who come from adverse socio-economic conditions such as refugees. ${ }^{57}$ To meet the needs of such learners, inclusive environments must provide the essential support to learners, educators and the entire system. ${ }^{58}$ As diversity among learners lies at the heart of an inclusive education system, inclusive education resonates with the Constitution by recognising diversity while resisting any form of exclusivity. ${ }^{59}$ As such, inclusive education is based on the constitutional values of human dignity, equality, and human rights and freedoms. ${ }^{60}$

Although the question has been raised whether inclusive education, in instances where formal equality is applied, is in the best interests of learners with special needs, ${ }^{61}$ in embracing an inclusive education system, South Africa clearly indicated a desire to remove all discriminatory practices in the provision of education. ${ }^{62}$ Conversely, this necessitates a radical reconstruction of schools and schooling, ${ }^{63}$ which in turn needs to be constructed by a discourse community in an interactive process that includes ongoing conceptualising and theorising, practice, reflection and research on practice. $^{64}$

54 Du Plessis "Barriers to Learner Performance: Learning From Turnaround Efforts in Low Performing Schools" 2015 Journal of Educational Studies 109110.

55 Department of Education Education White Paper 6. Special Needs Education: Building an Inclusive Education and Training System.

56 Pillay "Early Education of Orphans and Vulnerable Children: A Crucial Aspect for Social Justice and African Development - Original Research" 201883 Koers 1 3; Knowles "Vulnerability: Self-Study's Contribution to Social Justice Education" 201432 Perspectives in Education 8993.

57 Maguvhe 2015 African Journal of Disability 5.

58 Kamga 2016 CILSA 31

59 Nel, Tlale, Engelbrecht and Nel "Teachers' Perceptions of Education Support Structures in the Implementation of Inclusive Education in South Africa" 201681 Koers 11

60 Maguvhe 2015 African Journal of Disability 1.

61 Malherbe "The Constitutional Dimension of the Best Interests of the Child as Applied in Education" 20082 Tydskrif vir Hedendaagse Romeins-Hollandse Reg 267284.

62 Zhou and Yang "Literacy Education in China Within an Inclusive Education Context" 2016 32 Per Linguam 88 91; Mohangi and Berger "Inclusive Education and Educational Psychology: Forging Alliance for Support of Inclusion at School Level in South Africa" 2015 14 Journal of Educational Studies 6783.

63 Walton "'They Discluded Me': Possibilities and Limitations of Children's Participation in Inclusion Research in South Africa" 201129 Perspectives in Education 8385.

64 Walton and Lloyd "An Analysis of Metaphors Used for Inclusive Education in South Africa" 201143 Acta Academica 17. 


\section{A LEGISLATIVE FRAMEWORK}

To address the extent to which effect is given to refugee children's fundamental rights to life and to a basic education in South Africa, as well as the challenges that this presents, it is essential to take cognisance of the contextual legislative framework.

\section{International and regional law}

The United Nations Convention Relating to the Status of Refugees ${ }^{65}$ is one of the main international legal instruments regulating the responsibilities of refugees - namely, to obey the laws and regulations of the country in which they live and to take measures to maintain public order in such a country. The Convention on the Rights of the Child, ${ }^{56}$ in addition, sets widespread standards regarding most facets of a child's life. Of particular importance is its non-discrimination clause, Article 22, which provides that refugee children are equally entitled to all benefits bequeathed by law upon citizens. ${ }^{67}$ Although the realisation of the rights to, inter alia, a basic education and an acceptable standard of living is subject to the available resources at the disposal of government, ${ }^{68}$ this means that refugees and citizens must be treated equally. As a result, this Convention grants suitable protection as well as humanitarian support to refugee children for the enjoyment of their relevant rights. The 1995 Revised UNHCR Guidelines on Policies and Procedures in Dealing with Unaccompanied Children Seeking Asylum ${ }^{69}$ entitle all children seeking asylum, particularly those who are unaccompanied, to special care and protection. Of particular importance for this article is the fact that these Guidelines also provide that every child should have access to education in his or her asylum country.

At a regional level, the 1969 Organisation of African Unity Convention Governing the Specific Aspects of Refugee Problems in Africa ${ }^{70}$ merits attention. As Africa's own continental refugee instrument, the Convention identifies the responsibilities of both receiving states and states of origin. It provides that all refugees must be treated in accordance with assured human rights and refugee-specific standards. Receiving states are obliged under Article 11(2), within the parameters of their national legislation, to admit refugees within the borders of their country and to provide them with

65 UNHCR "Policy on Refugee Women and Guidelines on Their Protection: An Assessment of Ten Years of Implementation" (1991) www.refworld.org/pdfid/48aa83220.pdf (accessed 2018-09-14).

66 UNICEF Convention on the Rights of the Child (20 Nov 1989) preamble http://digitalcommons.ilr.cornell.edu/child/8 (accessed 2019-03-08).

67 Swart "Unaccompanied Minor Refugees and the Protection of Their Socio-Economic Rights Under Human Rights Law" 20099 African Human Rights Law Journal 103105.

68 Department of Education Education White Paper 6. Special Needs Education: Building an Inclusive Education and Training System.

69 Organisation of African Unity Convention Governing the Specific Aspects of Refugee Problems in Africa (1997) Office of the United Nations High Commissioner for Refugees.

70 OAU 1001 U.N.T.S. (1969), http://www.refworld.org/docid/3ae6b36018.html (accessed 2018-11-10). 
international protection so that they are not forced to return to danger, if such refugees, for well-founded reasons, cannot return to their homeland. States of origin, on the other hand, are obliged to facilitate the safe and secure return of refugees originally fleeing from their borders, and who thereafter wish to return. Such states must, according to Article 5(4), also ensure that persons, on return, are not reprimanded in any manner and thus that they are guaranteed all rights, responsibilities and freedoms associated with citizenship. The aim is to allow refugees to return to their homelands without fear or prejudice and to be able to live peaceful lives in their country of origin.

\section{South African law}

The Constitution guarantees for everyone the fundamental rights to human dignity and to life, as well as the right to a basic education. ${ }^{71}$ Furthermore, it makes provision for an equality clause unequivocally stating that everyone is equal before the law and has the right to equal protection and benefit of the law. ${ }^{72}$ As such, everyone is entitled to the full and equal enjoyment of all rights and freedoms. The State and all other persons are prohibited from, directly or indirectly, unfairly discriminating against anyone on one or more grounds, including ethnic or social origin, culture, language and birth. ${ }^{73}$ In order to prevent and prohibit future unfair discrimination, section 9(4) obliges the State to enact, to this effect, legislation that is applicable to all spheres of society.

With regard to giving effect to everyone's right to a basic education on an equal basis, South Africa has addressed these issues in documents such as the Disability Rights Charter of South Africa of 1992, the 1997 White Paper on Integrated National Disability Strategy and the 2001 Education White Paper 6 on Special Needs Education: Building an Inclusive Education and Training System. These documents all propose and outline strategies for education in line with the transformative nature of the Constitution ${ }^{74}$ in order to provide equitable quality education to all learners within the frontiers of this country.

White Paper $6^{75}$ advocates the introduction of an inclusive education system within which the unique needs of individual learners are respected and catered for. By acknowledging that all learners have the potential to learn, if given the necessary support, it recognises that an education system's failure to identify and house diverse learning needs will result in a breakdown of learning. In addition, guiding principles are provided; these include the protection of the rights and the fair treatment of all learners, as well as the provision of equal access to education and the assurance of full

Constitution, ss 10, 11 and 29.

Constitution, s 9 .

Constitution, $s$ 9(3).

Kamga 2016 CILSA 34

Department of Education Education White Paper 6. Special Needs Education: Building an Inclusive Education and Training System. 
and meaningful participation by all learners in the teaching and learning process in schools and in society. ${ }^{76}$

The South African Schools Act ${ }^{77}$ (Schools Act) and the National Education Policy $\mathrm{Act}^{78}$ are two examples of legislation being enacted to ensure the provision of education without any form of unfair discrimination. The Schools Act aims at giving effect to the values entrenched and the fundamental rights guaranteed in the Constitution in the education sphere. To combat discrimination, this Act prohibits any admission tests for learners to public schools and requires that all learners' educational needs must be met equally. As such, the affirmation of equal access and quality education for all learners is one of the key features of the Schools Act. The principle of quality education is highlighted in section 20(1)(a), stipulating that governing bodies of schools must promote the best interests of schools through the provision of quality education to all learners. Both this Act and the Admission Policy ${ }^{79}$ are, however, silent about the admission of refugee learners and, accordingly, do not respond to the State's international responsibility to accommodate such learners at public schools.

In giving effect to the aim of the Constitution - namely, to improve the quality of life of all citizens and free the potential of each person - the National Education Policy Act demands a school curriculum that aims at developing the full potential of each learner. It aims at creating lifelong learners who are confident and independent, literate, numerate and multiskilled, compassionate, with a respect for the environment and the ability to participate in society as critical and active citizens. Again, no mention is made of refugee children specifically.

The Refugee Act, $^{80}$ on the other hand, guarantees certain rights to refugees in order that they might enjoy living at least a decent and dignified life. These, according to section $27(a)-(e)$, include the rights to education and freedom of movement, and to be issued with identity and travel documents. This Act deals extensively with the legal position of refugees, as non-citizens, by providing them with full legal protection plus an entitlement to the fundamental rights as set out in the Bill of Rights. The right of refugees to education is specified in section $27(\mathrm{~g})$, providing them with an entitlement to exactly the same basic primary education which all inhabitants in this country may receive from time to time.

\footnotetext{
Department of Education Admission Policy for Ordinary Schools (1999)

84 of 1996.

27 of 1996.

Department of Education Admission Policy for Ordinary Schools (1999).

130 of 1998 as amended by the Refugees Amendment Act 33 of 2008.
} 


\section{THE ROLE OF EDUCATION IN THE REALISATION OF REFUGEES' RIGHT TO LIFE}

Educating all of our children must be one of our most urgent priorities. We all know that education, more than anything else, improves our chances of building better lives.

The living of a peaceful and good life in a receiving country for refugees entails much more than the absence of violence or having financial security. Since human needs are interrelated and interdependent, ${ }^{82}$ living good lives also requires psychological harmony resulting from the satisfaction of other basic human needs such as education.

Bekink and Bekink ${ }^{83}$ highlight the extremely important role played by education for its potential to advance and expand human autonomy as well as in acquiring life and social skills in order not only to function independently, but also contribute to society's life at large. Education leads to a better understanding of the immediate environment and the rest of the world, ${ }^{84}$ facilitates intercultural communication by enhancing language and communication skills, prepares humans for future employment guaranteeing financial security and reduces human ignorance - a prerequisite for wellbeing. ${ }^{85}$ The right to education is, subsequently, widely recognised as a fundamental right upon which the exercise of other civil, political, economic, social and cultural rights are dependent. The rights to freedom of expression and to participate in cultural life are, for example, fundamentally interwoven with the right to a basic education, as they can only be meaningfully exercised once a certain minimum level of education has been achieved. Thus, education fulfils not only a qualification function but also the social needs of all humans. ${ }^{86}$ This is confirmed in the preamble to the Constitution, which aims at freeing the potential of everyone by recognising the important role of education in meeting the needs of learners as it empowers them to be able to survive, to develop their full capacities, to live and work with dignity, to improve the quality of their lives, to make informed decisions, and to continue learning.

Receiving education in an inclusive education system is even more important because of its ability to transform an entire society and endorse the democratic values attached to human rights. Such an education celebrates diversity among humans and also brings about changes in personal beliefs, attitudes and behaviour - all necessary to create entirely new lifestyles. ${ }^{87}$ Being educated among children from different backgrounds and with diverse abilities enhances learners' interaction and participation

\footnotetext{
Mandela Nelson Mandela: The Authorised Book of Quotations (2011) 129.

Spreen and Vally 2012 Southern African Review of Education 74.

"Children with Disabilities and the Right to Education: A Call for Action" 20051 Stellenbosch Law Review 125128.

Meltz et al 2014 SAJE 4

55 Spreen and Vally 2012 Southern African Review of Education 75.

Bekink and Bekink 2005 Stellenbosch Law Review 134.

87 Maguvhe 2015 African Journal of Disability 6.
} 
skills in a transformative, diverse, human rights and democratic world. ${ }^{88}$ An inclusive education system can thus provide refugee children with the necessary tools to become full members of a community again and to live full lives. ${ }^{89}$ This aspect was emphasised by the South African Human Rights Commission ${ }^{90}$ in finding that learners most disadvantaged in enjoying their fundamental right to a basic education normally lack the means and social power to speak out and claim their rights.

Inclusive education can, moreover, instil hope for future life by providing refugee children (who may not know who they really are because of the misery and harsh conditions they have had to endure $)^{91}$ with a sense of belonging and resilience - that is, the ability to recuperate from trauma and cope with high levels of stress despite continuous misfortune. ${ }^{92}$ This is because inclusive education aims at providing a wider spread of education support services for all learners. ${ }^{93}$

Despite these benefits, the inclusion of refugee learners in an inclusive education system is often highly underemphasised. ${ }^{94}$ Refugees are too often regarded as political objects expelled from their natural homes and entitled only to a speechless bare life, rather than as political subjects whose ideas and future lives are shaped by the social environments in which they live. ${ }^{95}$ This, according to various authors, ${ }^{96}$ is a global phenomenon as the political will to accept refugees is fading owing to poor economic conditions around the globe. The lack of political will to follow a humanitarian approach towards ensuring a better quality of life for all humans, rather than selfishly protecting own economic sources, was condemned by the Constitutional Court in $S \mathrm{v}$ Makwayane and Mchunu, ${ }^{97}$ which indicated that such an approach will leave the social outcasts, the vulnerable, minority groups and others who cannot protect their own rights adequately through a democratic process, ultimately exposed and totally unprotected. Referring to the purported protection of refugees as a smokescreen characterised by negligence, avoidance and

88 Selesho "The Challenges Faced By Student Teachers Towards Inclusion of Learners With Special Educational Needs in the Mainstream" 201211 Journal of Educational Studies 98 108.

89 Makoni and Higgs "The Nature of Peace Education in African Indigenous Knowledge Systems" 201615 Indilinga African Journal of Indigenous Knowledge Systems 191198.

90 "Report of the Public Hearing on the Right to Basic Education" (10 July 2006) https://www.sahrc.org.za/home/21/files/Reports/Right\%20to\%20basic\%20education\% 202006.pdf (accessed 2018-09-18) 13.

91 Spreen and Vally 2012 Southern African Review of Education 73.

92 Sleijpen, Boeije, Kleber and Mooren "Between Power and Powerlessness: A MetaEthnography of Sources of Resilience in Young Refugees" 201621 Ethnicity and Health 158160.

93 Ngwena and Pretorius "Substantive Equality for Disabled Learners in State Provision of Basic Education: A Commentary on Western Cape Forum for Intellectual Disability $v$ Government of the Republic of South Africa" 201228 SAJHR 8190.

94 Selesho 2012 Journal of Educational Studies 98108.

95 Williams 2014 Acta Academica 117

96 Crisp Mobilizing Political Will for Refugee Protection and Solutions: A Framework for Analysis and Action (2018) World Refugee Council Research Paper 1; Bekker "The Protection of Asylum Seekers and Refugees Within the African Regional Human Rights System" 201313 African Human Rights Law Journal 128.

971995 (3) SA 391 (CC). 
glaring flaws, Van Lennep ${ }^{98}$ shows that litigation has become a crucial source of refugee support in order to highlight the discrepancy between the rights protected in the Constitution and the prevailing actions of government creating administrative barriers for refugees.

\section{CITIZENS, REFUGEES AND HUMAN RIGHTS IN THE SOUTH AFRICAN CONTEXT: THE CHALLENGES}

Section 3 of the Constitution entitles all citizens - adults and children - to rights, privileges and benefits of citizenship involving a sense of true equality and justice. However, citizenship also goes along with duties and responsibilities that require an understanding of cultural and social inequalities, as well as active involvement in all decisions affecting human lives. ${ }^{99}$ Although citizenship provides citizens with an identity and empowers humans to exercise a degree of control over and determine their own lives, ${ }^{100}$ it also obliges them to take responsibility for creating a caring society in which the quality of life lived by non-citizens and future generations can be fulfilled. ${ }^{1}$

Once citizenship is granted, a contractual social, political and legal relationship is created in terms of which the State also incurs specific duties, of which the securing of fundamental rights is paramount. ${ }^{102}$ With the exception of sections $3,19,20(3), 21(4), 22,25(5), 37(6)-(8)$ and 47 of the Bill of Rights (which grant citizens a privileged legal position pertaining to political participation as well as access to certain civil and political rights), all other fundamental rights are guaranteed equally to non-citizens living in South Africa, as confirmed by the court in Patel v Minister of Home Affairs. ${ }^{103}$ Although the rights reserved for citizens alone cannot be claimed by refugees - not even under the guise of the equality provision ${ }^{104}$ - the State is obliged to respect, protect, promote and fulfil the fundamental rights guaranteed in the Bill of Rights and is authorised to determine, through legislation, the rules under which such rights may be exercised. ${ }^{105}$

In holding the State accountable in this regard, the judiciary plays an important role. With specific reference to unaccompanied refugee children in need of care, the court in the Centre for Child Law v Minister of Home

98 Van Lennep "The State of the South African Refugee Protection Regime: Part I - Current Status" Helen Suzman Foundation https://hsf.org.za/publications/hsf-briefs/the-state-of-thesouth-african-refugee protection-regime-part-i-cur (accessed 2019-03-04).

99 Koopman "Citizenship in South Africa Today - Some Insights from Christian Ecclesiology" 201543 Southern African Journal of Mission Studies 425427.

100 Abdulbari "Identities and Citizenship in Sudan: Governing Constitutional Principles" 201313 African Human Rights Law Journal 383386.

101 Bekink and Bekink 2005 Stellenbosch Law Review 144.

102 Okoth-Obbo "Does Refugee Protection in Africa Need Mediation?" 20009 Refugees, Conflict and Conflict Resolution 12.

1032000 (2) SA 343 (D).

104 Constitution, s 9; Visser "The Registration of Refugees as Security Service Providers" 2004 Tydskrif vir Hedendaagse Romeins-Hollandse Reg 9495.

105 Constitution, s 7(2). 
Affairs, ${ }^{106}$ for example, found that the provisions of the Children's Act ${ }^{107}$ apply equally to such children, thus making the South African government directly responsible for the fulfilment of the socio-economic and education needs of refugee children. To avoid the risk of replacing humanity with citizenship, discrimination against refugees on the basis of citizenship was also found to be unfair by the Constitutional Court in Khoza v Minister of Social Development. ${ }^{108}$ The reason for this decision was that the exclusion of refugees from state benefits would have a severe impact on their human dignity as it would deprive them of access to the bare necessities of life. Directly or indirectly barring refugees from access to social services was also criticised in Bishogo $v$ The Minister of Social Development. ${ }^{100}$

Owing to its welcoming approach towards refugees in the past, ${ }^{110}$ South Africa has experienced an extraordinary increase in both illegal and legal refugees since $2000 .{ }^{111}$ This, according to Kloser, ${ }^{112}$ created a risk for South Africa of being overwhelmed and its social security endangered. It even allowed the influx of criminal-minded refugees, endangering the lives of South Africans. ${ }^{113}$ The tension created by this influx, as well as the challenges it presents in realising the rights to life and a basic education of refugees, are outlined next. The well-acknowledged seven main barriers impeding the realisation of inclusive education identified by White Paper $6^{114}$ are used as a framework to demarcate the challenges presented specifically by refugee learners.

\section{Socio-economic barriers}

Socio-economic barriers such as poverty, poor living conditions and scarce resources prevalent in South Africa ${ }^{115}$ are some of the elements identified as thwarting inclusiveness and the potential to apply the principles of social justice (equitable outcomes for all) and promote the nurturing of social cohesion ${ }^{116}$ to ensure better lives for all. ${ }^{11}$

\footnotetext{
2005 (6) SA $50(T)$.

38 of 2005.

2004 (6) SA 505 (CC).

109 Unreported Transvaal Provincial Division, Case 9841/2005.

110 Steyn, Kotze and Taylor 2011 Africa Insight 107.

111 Mukonza 2011 Journal of Public Administration 1388.

112 Irregular Migration, State Security and Human Security. Paper presented for the Policy Analysis and Research Programme of the Global Commission on International Migration, University of London (September 2005) 110.

113 Mahr "South Africa's Role as a Refugee Haven May Be Coming to an End" (15 February 2007) https://www.washingtonpost.com/news/worldviews/wp/2017/02/15/south-africas-roleas-a-refugee-haven-may-be-coming-to-an-end/ (accessed 2019-03-05).

114 Department of Education Education White Paper 6. Special Needs Education: Building an Inclusive Education and Training System.

115 Nel, Müller, Hugo, Helldin, Bäckmann, Dwyer and Skarlind "A Comparative Perspective on Teacher Attitude-Constructs That Impact on Inclusive Education in South Africa and Sweden" 201131 South African Journal of Education 7476.

116 Spreen and Vally 2012 Southern African Review of Education 74.
} 
Conflict arises when accepting large numbers of refugees into South Africa inevitably leads to citizens having to compete with them for scarce resources such as employment opportunities (given a 26,7 per cent unemployment rate) and the delivery of basic services generally associated with citizenship. ${ }^{118}$ Given that providing equal educational opportunities for all citizens remains a challenge (280 000 South African learners do not have access to basic education), ${ }^{119}$ providing education to refugees automatically creates tension. In line with this, Nel et al ${ }^{120}$ opine that schools in both urban and rural areas simply do not have the capacity to accommodate a larger number of potential learners in this country.

Thus, it comes as no surprise that studies conducted ${ }^{121}$ found that 35 per cent of refugee children do not have access to public schools. Some refugee children were found to receive education at a Johannesburg school run by a group of civil society organisations after school hours, or at the St Albert Street Refugee School run by the Central Methodist Church. ${ }^{122}$ However, such practices are criticised as they lead to multi-layered notions of, and dissonant theories regarding the concepts of exclusion and inclusion. ${ }^{123}$ Accommodating refugee learners after school hours at public schools or at privately funded or welfare institutions may create the impression of inclusion but, in reality, the learners remain excluded. ${ }^{124}$ In this regard, Kamga ${ }^{125}$ advocates that rights-based legislation and social policies that follow a distributional pattern centred on all the neediest in the education sector should be adopted by government.

Government, however, finds itself in a stressed position. It is, on the one hand, obliged to guarantee that the needs of its citizens, especially the poor, are met, while, on the other hand, being required to adhere to international humanitarian responsibilities by ensuring human sanctuary for and respecting the human rights of all refugees. ${ }^{126}$ Since large numbers of citizens still live in great poverty ${ }^{127}$ excluding them from the social security system, despite the constitutional promise of a better quality of life for all

117 Geldenhuys and Wevers "Ecological Aspects Influencing the Implementation of Inclusive Education in Mainstream Primary Schools in the Eastern Cape, South Africa" 201333 South African Journal of Education 12.

118 Steyn, Kotze and Taylor 2011 Africa Insight 88.

119 Mampane "Resilience in the Continuum of Support, Juxtaposing Inclusive Education and Special Education Systems" 201622 Southern African Review of Education 115 121; Hall Children's Access to Education, South African Child Gauge (2015) 151.

120 Spreen and Vally 2012 Southern African Review of Education 74.

121 Spreen and Vally 2012 Southern African Review of Education 71; Mukonza 2011 Journal of Public Administration 1392.

122 Pausigere 2013 Perspectives in Education 45.

123 Sookrajh, Gopal and Maharaj "Interrogating Inclusionary and Exclusionary Practices: Learners of War and Flight" 200523 Perspectives in Education 14.

124 Ibid.

1252016 CILSA 52.

126 Mukonza 2011 Journal of Public Administration 1390.

127 Olivier, Smit and Kalula (eds) Social Security: A Legal Analysis (2003) 26. 
citizens, ${ }^{128}$ the government may be tempted and even pressured into favouring the needs of its citizens above those of refugees. However, whenever it denies non-citizens access to socio-economic rights, such denial must be justified in terms of the limitation clause ${ }^{129}$ in order to prevent unjust limitations. Unfortunately, the possibility exists that the limitation clause may be used robustly against refugees in favour of citizens.

However, this may not be the only option. Using Lesotho as an example, Mariga, McConkey and Myezwa ${ }^{130}$ found that inclusive education can indeed succeed without a wealth of resources. Similarly, Naicker ${ }^{131}$ found that socioeconomic barriers are created mainly by poor planning and mismanagement of available resources at different levels of the education system. For example, government is criticised for the ongoing allocation of resources to already well-established special schools, instead of to inclusive mainstream schools in order to improve the overall quality of education received by learners in an inclusive education system. ${ }^{132}$ In light of the nexus between receiving high-quality and equitable education, and living high-quality lives, Maguvhe ${ }^{133}$ emphasises the need for all to understand the transformational and human-rights value of inclusive education. The responses of the participants to his study, for example, differed radically with regard to the extent to which inclusive education can transform, add value or play an advocacy role in the lives of learners and the broader community. As a result, commentators advocate for collaboration between all educational role-players with a mutual set of objectives and a belief in social justice ${ }^{134}$ to meet the needs of all children as a vulnerable group. ${ }^{135}$ Coordination between educational stakeholders and other state departments is equally important if government to is to realise its constitutional mandate to give effect to the right to a basic education for all within its borders. ${ }^{136}$

\section{Attitude barriers}

The large inflow of refugees into South Africa has disrupted this country's population dynamics and had a visible effect on citizens' attitudes and political self-importance. ${ }^{137}$ Accordingly, instead of being welcomed,

128 Constitution, preamble; Prinsloo "Implementation of Life Orientation Programmes in the New Curriculum in South African Schools: Perceptions of Principals and Life Orientation Teachers" 200727 South African Journal of Education 155157.

129 Constitution, s 36

130 Inclusive Education in Low-Income Countries (2014) 30.

131 "From Policy to Practice: A South African Perspective on Implementing Inclusive Education Policy" 20063 International Journal of Whole Schooling 12.

132 Mampane 2016 Southern African Review of Education 122; Donohue and Bornman "The Challenges of Realising Inclusive Education in South Africa" 201434 South African Journal of Education 14 ; Geldenhuys and Wevers 2013 SAJE 4; Acedo "Inclusive Education: Pushing The Boundaries" 200838 Prospects 56.

133 Selesho 2012 Journal of Educational Studies 98108.

134 Spreen and Vally 2012 Southern African Review of Education 75.

135 Mohangi and Berger 2015 Journal of Educational Studies 82.

136 Spreen and Vally 2012 Southern African Review of Education 80.

137 Landau and Jacobsen 2006 Forced Migration Review 47. 
foreigners are bombarded by incidents of xenophobia, ${ }^{138}$ discrimination, ${ }^{139}$ social exclusion, ${ }^{140}$ hatred, ${ }^{141}$ harassment ${ }^{142}$ and criminal activities. ${ }^{143}$

Despite the imperative provision that the best interests of children should always be paramount, ${ }^{144}$ refugee children are unfortunately also targeted in these incidents. Such children are often isolated by community members in the belief that they are responsible for bringing diseases such as HIV into the country and for perpetrating crime in South Africa. ${ }^{145}$ Some are even outrightly prevented from enrolling in public schools, ${ }^{146}$ despite the potential of schools to create safe havens where children can freely learn, socialise and heal ${ }^{147}$ while being educated, empowered and recreated in their own lives. ${ }^{148}$ As such, refugees are deprived of the potential of inclusive schools to offer them comfort as well as psychological and emotional support. ${ }^{149}$ In this regard, it must be noted that refugee children, already traumatised by their experiences in their country of origin, ${ }^{150}$ are extremely prone to developing emotional trauma. Their ability to develop new skills and behaviour informed by the prevailing norms and values of their receiving states, ${ }^{151}$ and their resilience, is tested in all spheres of life - the communities they live in, the schools they attend and even the places they approach to access social services. ${ }^{152}$ This is extremely troublesome for refugee children as, in addition to intrinsic factors within themselves, negative attitudes and disrespect towards them are external factors over which they have no control but which, nevertheless, infringe on their right to a basic education and inhibit them from living full lives. ${ }^{15}$

The negative behaviour displayed by citizens towards refugees is, among others, the result of citizens believing that government should prioritise them

138 Sarr and Mosselson "Issues in Teaching Refugees in U.S Schools" in Faltis and Valdes (eds) Education, Immigrant Students, Refugee Students and English Learners (2010) 550.

139 UNICEF "Examples of Good Practices in the Implementation of the International Framework for the Protection of the Rights of the Child in the Context of Migration" (May 2010) United Nations Children's Fund.

140 Rutherford "Zimbabwean Farmworkers in Limpopo Province, South Africa" in McGregor and Primorac (eds) Zimbabwe's New Diaspora: Displacement and the Cultural Politics of Survival (2010) 61.

141 Kemper 2017 Servamus Community-Based Safety and Security Magazine 28.

142 Landau and Jacobsen 2006 Forced Migration Review 46.

143 Landau Exorcising the Demons Within 142; Addaney and Quan 2015 Without Prejudice 78.

144 Constitution, s 28(2).

145 Bekink and Bekink 2005 Stellenbosch Law Review 125128.

146 Rugunanan and Smit "Seeking Refuge in South Africa: Challenges Facing a Group of Congolese and Burundian Refugees" 201128 Development Southern Africa 705715.

147 Pacheco Exploring the Education Experiences of Sudanese Refugee Women Living in the United States (masters dissertation, Bowling Green State University) 201134.

148 Bekink and Bekink 2005 Stellenbosch Law Review 134.

149 Diphoko v Road Accident Fund 2013 JDR 1151 (GNP).

150 Rugunanan and Smit 2011 Development Southern Africa 717.

151 Sarr and Mosselson in Faltis and Valdes Education, Immigrant Students, Refugee Students and English Learners 554.

152 Meda "Resilience Among Refugees: A Case of Zimbabwean Refugee Children in South Africa" 201715 Child Abuse Research 6276.

153 Department of Education Education White Paper 6. Special Needs Education: Building an Inclusive Education and Training System. 
when it comes to protecting fundamental rights. ${ }^{154}$ Citizens are, moreover, of the view that government should use its sovereign right to control the country's borders to reduce the influx of refugees in order to fulfil its social safekeeping role towards its citizens. ${ }^{155}$

The Department of Education ${ }^{156}$ has identified the need for attitude and behaviour changes with regard to inclusiveness in order to maximise the participation of all learners at both schools and in society at large, seeing that learning is not limited to formal education spheres. Although studies found that educators in training generally demonstrate positive attitudes towards inclusive education, they do not fully comprehend the concept ${ }^{157}$ and have doubts regarding its ability to deliver high-quality education. ${ }^{58}$ In this regard, the importance of sufficient initial and ongoing in-service training based on a multicultural social justice approach for educators cannot be overemphasised; such training empowers educators to develop suitable knowledge, attitudes and skills to celebrate diversity among learners. Educators also need to be taught how to question society, its attitude towards inclusiveness and its account of the truth regarding refugee learners and their unique needs during initial and in-service training programmes. ${ }^{159}$

\section{Language and communication barriers}

Owing to the importance of language in knowledge acquisition, ${ }^{160}$ refugee children who are not proficient in one of South Africa's 11 official languages encounter communication and cognitive problems, resulting in high drop-out rates among refugees, similar to that of South African-born learners not proficient in the language of instruction. ${ }^{161}$ Moreover, it leads to refugee children being discriminated against and denied their basic human rights.

As a remedy, the Chitate Street School for Refugees was opened in 2008 with the aim of providing interim relief to refugees and to facilitate a smooth transition back to their countries of origin. Addressing the language barriers experienced by refugees in public schools is unfortunately not a priority

154 Pieterse "Foreigners and Socio-Economic Rights: Legal Entitlements or Wishful Thinking?" 20001 THRHR 5153.

155 Olivier, Smit and Kalula Social Security: A Legal Analysis 26

156 Department of Education Education White Paper 6. Special Needs Education: Building an Inclusive Education and Training System.

157 Makoni and Higgs 2016 Indilinga African Journal of Indigenous Knowledge Systems 191 198; Smit and Mpya "How Educator Perception Has Shaped Inclusive Teaching at a Rural Village School in South Africa" 201112 Child Abuse Research 2529.

158 Hanko "Towards an Inclusive School Culture: The Affective Curriculum" in Nind, Rix, Sheehy and Simmons (eds) Curriculum and Pedagogy in Inclusive Education: Values Into Practice (2005) 142.

159 Lemmer and Meier "Initial Teacher Education for Managing Diversity in South Africa: A Case Study" 201110 Journal of Educational Studies 101103.

160 Engelbrecht, Oswald and Forlin "Promoting the Implementation of Inclusive Education in Primary Schools in South Africa" 200633 British Journal of Special Education 121123.

161 Dryden-Peterson The Education Experiences of Refugee Children in Countries of First Asylum (2015) 18.

162 Meda 2017 Child Abuse Research 78. 
given that the South African public schooling system is still far from providing education in all its official languages.

\section{School environments as a barrier to learning and development}

Although South Africa has introduced various instruments to create inclusive education environments, its formation involves much more than a reform process. ${ }^{163}$ It necessitates an evolving and never-ending process posing abundant challenges across multiple ecologies of the education system. ${ }^{164} \mathrm{It}$ also needs a totally new paradigm for education to remain relevant and to prepare learners for life itself. ${ }^{165}$ As a result, numerous authors globally report on the complexity of the practical implementation of an inclusive education policy. ${ }^{166}$ In South Africa, specifically, studies have found that the transformation towards inclusive education environments is slow, ${ }^{167}$ incomplete, ${ }^{168}$ inconsistent ${ }^{169}$ and even going nowhere. ${ }^{170}$

Various contextual factors across the education sector that threaten the existence of conducive learning environments have been identified. ${ }^{171}$ Croll and Moses ${ }^{172}$ recognised the pervasiveness of hostile climates at public schools, while Magare, Kitching and Roos ${ }^{173}$ attribute such hostility to poverty, while Donohue and Bornman ${ }^{174}$ cite the presence of differences in opinion regarding the needs, beliefs and best practices of learners. In turn, according to Nel et al, ${ }^{175}$ environmental difficulties have led to South Africa

163 Nel et al 2016 Koers 2.

164 Mampane 2016 Southern African Review of Education 116; Oswald and De Villiers "Including the Gifted Learners: Perceptions of South African Teachers and Principal" 2013 33 South African Journal of Education 114.

165 Slabbert "Educational Change: Is It Possible?" 2001 Educare 289295

166 Hill, Baxen, Craig and Namakula "Citizenship, Social Justice and Evolving Conceptions of Access to Education in South Africa: Implications for Research" 201236 Review of Research in Education 239 256; Ngcobo and Muthukrishna "The Geographies of Inclusion of Students with Disabilities in an Ordinary School" 201131 South African Journal of Education 357 358; Nel et al 2011 SAJE 77; Ntombela "The Progress of Inclusive Education in South Africa: Teachers' Experiences in a Selected District, Kwazulu-Natal" 2011 Improving Schools 5 14; Paugh and Dudley-Marling, "'Speaking' Deficit Into (Or Out Of) Existence: How Language Constrains Classroom Teachers' Knowledge About Instructing Diverse Learners" 201115 International Journal of Inclusive Education 819 831; Miles and Singal "The Education for All and Inclusive Education Debate: Conflict, Contradiction or Opportunity?" 201014 International Journal of Inclusive Education 13.

167 Mampane 2016 Southern African Review of Education 122.

168 Wildeman and Nomdo Implementation of Inclusive Education: How Far Are We? Occasional Paper (2007)

169 Meltz et al 2014 SAJE 7; Basson "Adaptation, Evaluation and Inclusion" 20118 Africa Education Review 193198.

170 Selesho 2012 Journal of Educational Studies 98108.

171 Geldenhuys and Wevers 2013 SAJE 5.

172 "Ideologies and Utopias: Education Professionals' Views of Inclusion" 200015 European Journal of Special Needs Education 17.

173 "Educators' Experiences of Inclusive Learning Contexts: An Exploration of Competencies" 201028 Perspectives in Education 5253.

1742014 SAJE 3.

1752011 SAJE 84. 
having proportionately more learners with barriers to learning than countries such as Sweden.

In order to create conducive school environments, Walton, ${ }^{176}$ together with various other national authors ${ }^{177}$ recommends that listening to the voice of all learners, who inside experts through experience, could be the answer. Such learners could make valuable contributions with regard to what real inclusion entails, what their needs are exactly and what a true welcoming environment should comprise.

\section{Inaccessible support services as barriers}

The practice of inclusive education is underpinned by the provision of solid and constant support, thus demanding the presence of pertinent support structures, ideal systems and methodologies enabling schools to deliver high-quality education on an equal basis to all learners. ${ }^{778}$ The latter requires that the unique, complex and diverse needs of all learners are adequately identified, respected and met. ${ }^{179}$ Conversely, if such needs are not met with the assistance of efficient support services, an inclusive education classroom can worsen the life experiences of refugee children. ${ }^{180}$ To avoid this, refugee children, who have already experienced excessive trauma in their lives, require the provision of educational psychology services at schools in order to assist them to adopt new skills, to acquire a futurelooking mind-set and to engage with the socio-economic realities of life. ${ }^{181}$

\section{Lack of parental involvement as barrier}

Lack of parental involvement in the education of their children is even more of a problem when it comes to refugee learners. This is mainly due to large numbers of unaccompanied children fleeing their country of origin, parents not being conversant in the language of instruction and so being unable to assist their children, illiteracy among parents ${ }^{182}$ and even parents hiding in order to conceal their true identities as refugees for fear of being deported. ${ }^{183}$ Emphasis was, in this regard, placed by the High Court in the Centre for Child Law $v$ Minister of Home Affairs ${ }^{184}$ on the duty of the State to ensure

1762011 Perspectives in Education 84.

177 Allan Rethinking Inclusive Education (2007) 15; Lewis "Reflecting on Interviewing Children and Young People as a Method of Inquiry in Exploring Their Perspectives on Integration/Inclusion" in Sheehy, Nind, Rix and Simmons (eds) Ethics and Research in Inclusive Education (2005) 216; Masson "The Legal Context” in Fraser, Lewis, Ding, Kellett and Robinson (eds) Doing Research With Children and Young People (2004) 45.

178 McLeskey, Waldron and Reddy "A Case Study of a Highly Effective, Inclusive Elementary School" 201448 Journal of Special Education 5968.

179 Department of Education Education White Paper 6. Special Needs Education: Building an Inclusive Education and Training System.

180 Malherbe 2008 THRHR 267272.

181 Mohangi and Berger 2015 Journal of Educational Studies 83.

182 Smit and Mpya 2011 Child Abuse Research 33.

183 Sarr and Mosselson in Faltis and Valdes Education, Immigrant Students, Refugee Students and English Learners 557.

184 Supra par 17. 
that such children's basic socio-economic needs (of which education is one) are taken care of.

\section{Human resource development as barrier}

Although the number of learners gaining access to both public mainstream and special schools has increased during the period of 2001 to 2013, 21 per cent fewer educators were employed during the same period. ${ }^{185}$ Since the pre- and in-service training of educators in inclusive education has not received the attention it deserved, the delivery of high-quality education is questionable, given the importance of well-equipped and innovative educators for the success of inclusive education. ${ }^{186}$ The main reason provided for the inadequate appointment and training provided thus far has been the current socio-economic environment in South Africa. ${ }^{187}$

Accordingly, the majority of educators feel unprepared, ${ }^{188}$ unsupported, ${ }^{189}$ insecure and inadequate, ${ }^{190}$ overwhelmed and ignored when decisions are taken, and thus threatened. ${ }^{191}$ Educators, moreover, lack the necessary skills with regard to teaching large numbers of diverse learners ${ }^{192}$ within an inclusive education system. As a result, educators and the entire education system continue to tussle with the effective implementation of inclusive classrooms. $^{193}$

\section{CONCLUSION}

Be ashamed to die until you have won some victory for humanity. ${ }^{194}$

A society's respect for human rights, its level of maturity and its creation of a caring environment can be evaluated by delineating the status that it accords

185 Mampane 2016 Southern African Review of Education 124.

186 Geldenhuys and Wevers 2013 SAJE 9.

187 Pillay and Di Terlizzi "A Case Study of a Learner's Transition from Mainstream Schooling to a School for Learners with Special Educational Needs: Lessons for Mainstream Education" 200929 SAJE 491502.

188 Magare et al 2010 Perspectives in Education 61; Pieterse Establishing a Framework for an Integrated, Holistic, Community 201075.

189 Mudzielwana and Runhare "Promoting Inclusivity Within Multidimensional Classroom Settings: The Prior-Knowledge and Experiences of Practising University Student Teachers Enrolled for the Advanced Certificate in Inclusive Education" 201413 Journal for Educational Studies 4246.

190 Rapmund and Moore "Enhancing Learners' Personal Resources through Narrative: Embracing Diversity" 200232 South African Journal of Psychology 2231.

191 Nel et al 2011 SAJE 83.

192 Selesho 2012 Journal of Educational Studies 107; Chataika, Mckenzie, Swart and LynerCleophas "Access to Education in Africa: Responding to the United Nations Convention on the Rights of Persons" 201227 Disability and Society 385 396; Dalton, Mckenzie and Kahonde "The Implementation of Inclusive Education in South Africa: Reflections Arising from a Workshop for Teachers and Therapists to Introduce Universal Design for Learning" 20121 African Journal of Disability 15.

193 McLeskey et al 2014 Journal of Special Education 69.

194 Mann Massachusetts Board of Education Annual Report, together with the Report of the Secretary of the Board (1838) 1837-1841. 
to the most vulnerable members of its society, the extent to which it provides such members who, despite all the odds, seek to regularise their presence in the country. South Africa's generosity of spirit will be expanded and reinforced when the rights to life and a basic education belonging to all refugees are realised, and when the government accepts its responsibility towards the advancement of their well-being and quality of life. It is only then that refugees will be viewed as more than social outcasts or objects of pity, and rather be treated as humans with the potential to contribute to this country's growth. It is, however, essential that refugees accept their responsibilities to take measures to maintain public order in South Africa, and citizens their responsibility to respect cultural and social differences.

The overwhelming purpose of an inclusive education system must be to protect and safeguard equally the human rights and social needs of all learners within the country's borders. While dealing with concerns regarding access to education, government must, as set out by the 1951 Convention Relating to the Status of Refugees, take responsibility for its vital role in securing the necessary documentation that enable asylum seekers to obtain refugee status and, thus, to live without fear of deportation and to access the right to a basic education, which will improve their overall quality of existence.

In view of South Africa's limitations, especially to ensure the economic well-being of its people through, among others, the delivery of high-quality education and concomitant quality of life experiences, refugees should at least be treated and educated to such an extent that they may be empowered to return voluntarily to their country of origin where they could indeed make a difference in the lives of the many people who could not flee from such a country. It is argued that, if citizens could view refugees as potentially contributing to a better world for all to live in, it could counter the pre-occupation of citizens with their own domestic interests as opposed to those of refugees.

However, a number of barriers impeding the effective implementation of inclusive education, and the protection of fundamental rights of refugees, still exist. Such barriers include a lack of political will, the inadequacy and mismanagement of resources, negative attitudes towards refugees and a lack of genuine engagement with the provision of support structures. These are in addition to the lack of conducive environments, the need to enhance human capital, language differences and intrinsic factors inhibiting parental participation. In acknowledging that the optimal implementation of inclusive education environments requires an ongoing process, all must be reminded of the notions that "the art of living is more like wrestling than dancing" ${ }^{\text {"195 }}$ and that "nothing worth having comes easy". ${ }^{196}$

195 Aurelius "Life Quotes" https://www.goodreads.com/quotes/123384-the-art-of-living-is-morelike-wrestling-than-dancing (accessed 2019-05-1).

196 Roosevelt https://www.goodreads.com/quotes/312751-nothing-in-the-world-is-worth-havingor-worth-doing (accessed 2019-05-01). 